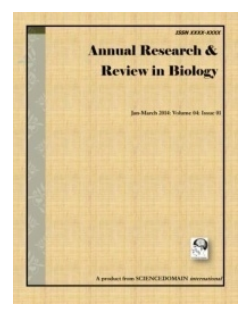

\title{
The Parenteral Feeding and Secretion of Regulatory Peptides in Infants
}

\section{Przemysław J. Tomasik ${ }^{1^{*}}$, Andrzej Wędrychowicz ${ }^{2}$, Andrzej Zając ${ }^{3}$, Miłosz Przybyszowski ${ }^{2}$, Mikołaj Spodaryk ${ }^{4}$, Krzysztof Fyderek ${ }^{2}$ and Krystyna Sztefko ${ }^{1}$}

${ }^{1}$ Department of Clinical Biochemistry, Collegium Medicum, Jagiellonian University, Wielicka St. 265, Krakow, Poland. ${ }^{2}$ Department of Pediatrics, Gastroenterology and Nutrition, Collegium Medicum, Jagiellonian University, Wielicka St 265, Krakow, Poland. ${ }^{3}$ Department of Pediatric Surgery Collegium Medicum, Jagiellonian University, Wielicka St. 265, Krakow, Poland. ${ }^{4}$ Andrzej Frycz Modrzewski KrakowUniversity, Herlinga-Grudzinskiego St.1, Krakow, Poland.

\section{Authors' contributions}

This work was carried out in collaboration between all authors. Author PJT designed and coordinated the study, performed biochemical analysis and drafted the manuscript. Authors $A W, A Z$, and MP enrolled patients to the study, collected the material, collected the clinical follow-up information and participated in drafting of the manuscript. Authors MS, KS and KF

consulted the results and participated in drafting of the manuscript. All authors read and approved the final manuscript.

Original Research Article

Received $21^{\text {st }}$ May 2014

Accepted $20^{\text {th }}$ June 2014

Published $5^{\text {th }}$ July 2014

\section{ABSTRACT}

Introduction: The direct effect of parenteral nutrition on secretion of regulatory peptides in infants has not been yet reported.

Aim: The aim of the study was the analysis of secretion of chosen regulatory peptides from the gut and adipose tissue in parenterally fed infants comparing to children fed orally as well as hydrated intravenously.

Materials and Methods: In this study, the response of glucose, ghrelin, leptin, PYY, GLP1 and adiponectin to the enteral and parenteral feeding in babies has been investigated. We compared three groups of infants: formula-fed infants, infants on TPN and fasted, awaiting for general anaesthesia before CT examination, receiving an i.v. $5 \%$ 
glucose/saline mixture. The blood samples were taken in first group prior and 60 minutes after feeding, in the second in continuous course of TPN and third after 8 hours fasting.

Results: Oral feeding does not influence plasma concentrations of leptin and adiponectin in infants. The ghrelin plasma concentrations during the total parenteral nutrition mimics the postprandial levels observed in enterally fed children. A significant positive correlation was found between calorie intake and adiponectin concentration $(r=0.76, p<0.001)$; and calorie intake and PYY concentration $(r=0.76, p<0.001)$ as well CCK $(r=0.50 ; p<0,005)$.

Conclusions: The lack of fasting/postprandial modulation of secretion of gut peptides might be responsible for disturbed development of parenterally fed children. Adiponectin and PYY are the putative marker of short-term energy balance.

Keywords: Ghrelin; leptin; GLP-1; CCK; adiponectin; PYY.

\section{ABBREVIATIONS}

BMI: Body mass index, CCK: Cholecystokinin, CT: computed tomography, GLP-1: Glucagon-like peptide-1, PYY: Peptide YY, TPN: Total parenteral nutrition.

\section{INTRODUCTION}

Oral self-feeding organisms regulate the amount of ingested energy/calories and their source. Under certain circumstances, when enteral feeding is impossible, all water, energy and body structure materials must be delivered directly to the vessels. During shorter periods of deprivation of enteral feeding, the organism may be intravenously supplemented with saline and glucose solutions, but during longer periods of food deprivation, parenteral nutrition is required. The proper calculation and composition of parenteral nutrition can be troublesome; however, some medical calculators can be evaluated for most typical patients. Calculation of nutritional needs in paediatrics is very difficult because nutrition should cover not only the basic functions of the body, but also proper growth and development of the child. It is also obvious that the composition of parenteral nutrition is quite different than oral nutrition. Parenteral nutrition is based on amino acids [except glutamine], glucose (simple carbohydrate) and emulsified triglycerides of plant origin. Due to the absence of typical oral feeding stimulants like proteins and fat, as well as the different point of delivery of the nutrients, serious disturbances in plasma concentrations of gastrointestinal peptides (like CCK, GLP-1, PYY, and ghrelin) and peptides from adipose tissue (like leptin and adiponectin) can be expected.

Ghrelin is a 28-amino acid peptide produced principally in the stomach and small intestine [1]. Initially, ghrelin was considered responsible for growth hormone release [2]. In adults ghrelin is up-regulated in fasting. Its increases just before meals, suggesting that ghrelin might act as a meal initiator; however, in infants and adolescents this peptide increases after a meal $[3,4]$. Ghrelin is also involved in long-term regulation - circulating levels of ghrelin are lower in obese and elevated in anorectic patients [5].

Peptide $Y Y$ is a 36 amino acid peptide secreted by $L$ cells localized in the ileum and colon. The plasma level of PYY increases after a meal and plateaus after one hour, there remaining stable for several hours [6]. PYY has been implicated in regulating the functions of the gastrointestinal tract: decreasing pancreatic exocrine, gastric and intestinal secretions, slowing gastric emptying and small intestine motility, and reducing blood flow to the 
gastrointestinal tract and pancreas [7]. PYY (3-36), acting as a terminator of hunger, also reduces appetite and 24 hour food intake by binding to the neuropeptide $Y$ receptor $Y 2$ in the hypothalamic arcuate nucleus [8].

GLP-1 (7-37) - glucagon like peptide-1 - is one of the final products formed from proglucagon in L cells in the ileum and colon. GLP-1 secretion is enhanced by alimentary fats and carbohydrates [9]. GLP-1 stimulates insulin secretion and inhibits pancreatic glucagon secretion. The insulinotropic action of this peptide begins when the blood glucose level exceeds $6 \mathrm{mmol} / \mathrm{l}$ [10]. GLP-1 also inhibits gastric acid secretion and gastric emptying [11]. Parenteral injection of GLP-1 or its analogues in obese men, and patients with diabetes mellitus t.2 produced a sensation of satiety and reduced the quantity of ingested food [12]. Wikarek et al. [13] observed a reverse correlation between postprandial GLP-1 level and hunger in men.

CCK is secreted from intestinal I cells after the ingestion of fats and proteins. CCK delays gastric emptying and stimulates gallbladder contraction [14]. CCK improves digestion through increasing exocrine pancreatic secretion. CCK also stimulates glucagon and pancreatic polypeptide secretion [15]. The incretin action of CCK in humans is still unclear [16]. Finally, CCK is a significant satiating factor of brain-gut axis [17].

Leptin, a hormone synthesized mainly by white adipose tissue, plays an important role in peripheral signalling, informing on accumulated energy stores and thus participating in longterm regulation of the amount of ingested food [18]. The plasma concentration of leptin depends directly on the adipose tissue mass and correlates with body mass index (BMI) [19].

Adiponectin, another hormone synthetized in large amounts by adipose tissue, lowers the plasma glucose level, sensitizes fibroblasts to insulin, and improves glucose phosphorylation, among other properties [20,21]. Adiponectin concentrations in the blood correlate negatively with insulin levels [22]. In humans, adiponectin levels are diminished in obese patients and elevated in malnourished patients with anorexia nervosa [23].

Changing the means of feeding is expected to alter the secretion of regulatory peptides from the gut and probably also the secretion of peptides from the adipose tissue. Deprivation of enteral feeding by substitution with parenteral nutrition may therefore influence an infant's development both short and long term. Therefore the aim of the study was to measure plasma levels of GI peptides such as ghrelin, CCK, PYY, and GLP-1 as well as peptides from adipose tissue such as leptin and adiponectin in infants on total parenteral nutrition.

\section{MATERIALS AND METHODS}

\subsection{Experimental Groups}

The children from group I ( $n=16,9$ girls and 7 boys) were fed exclusively with cow's milk formula (Bebilon 1; Nutricia - formula for younger infants, equal to Nutrilon 1), free of solids or mixed solids. All these children were healthy, mean age $4 \pm 1$ month. Their mean body mass was appropriate to their age and length $(5.5 \pm 0.8 \mathrm{~kg}$; mean BMl calculated using Eurogrowth 2.0.0 software was $16.3 \pm 1.2 \mathrm{~kg} / \mathrm{m} 2$; mean $z$-score for BMI was $-0.15 \pm 0.86$ ). Coexistence of other diseases and any hereditary connections were excluded in all the subjects. These children received a bottle on average 7 times a day, when they showed 
signs of hunger. In all cases the diet did not change for at least 2 weeks prior to blood test sampling. The calorie intake was adequate to the children's' age and body weight.

Group II [n=14, 6 girls and 8 boys] included infants requiring total parenteral nutrition for either congenital bowel atresia or acquired obstruction of the gastrointestinal tract (before or after surgery). The children were of similar age and weight (mean age $4 \pm 2$ months and mean weight $4.9 \pm 1.8 \mathrm{~kg}$; mean BMI calculated as above was $14.3 \pm 1.8 \mathrm{~kg} / \mathrm{m} 2$; mean $z$-score for BMI was $-1.5 \pm 1.84$ ) compared to children in group I. The children receiving total parenteral nutrition fully met their amino acid requirements (Vaminolact, Fresenius Kabi). The level of administered non-protein calories, i.e. $70 \%$ glucose, $30 \%$ lipid emulsion (Intralipid) was calculated based on the amount of infused amino acids (175 kcal of nonproteins per gram of amino acid nitrogen).

The children in Group III ( $n=15,6$ girls and 9 boys) were prepared for computed tomography of the head under sedation and, therefore were deprived of food for at least 8 hours prior to the imaging. During this period of time they received fluids $(0.9 \%$ saline and $5 \%$ glucose mixture $2: 1 \mathrm{v} / \mathrm{v}$ ) according to their specific requirements. The mean age in this group was $4.5 \pm 1.5$ month and mean weight was $6.3 \pm 1.9 \mathrm{~kg}$; mean BMI was $17.1 \pm 1.0 \mathrm{~kg} / \mathrm{m} 2$; mean zscore for BMI was $0.02 \pm 0.78$. These children had had some neurological disturbances such as seizures in the past, but the children finally recruited, based on physical examination and $\mathrm{CT}$, were free of pathologies.

\subsection{Study Protocol}

The Permanent Ethical Committee for Clinical Studies of the Medical College of Jagiellonian University approved the protocol for the study, and the parents of the examined children provided their signed consent.

Before feeding, the nude infants were examined and weighed with an electronic integrating balance. The crown-to-heel length was measured with $1 \mathrm{~mm}$ precision on a recumbent infant board. The percentage of ideal body weight (evaluated from the length-based weight estimation) was calculated using data appropriate for the Polish population [24].

A catheter was fixed in the vein of each child and venous blood was taken directly prior to the meal. Subsequently, children consumed a portion of formula and blood samples were collected 60 minutes after feeding. The mean volume of milk formula ingested per day was $820 \pm 120 \mathrm{ml}$. Consumption lasted no longer than 30 minutes (mean $16 \mathrm{~min}$ ). In children with total parenteral nutrition, blood was taken only once, after a minimum $24 \mathrm{~h}$ of continuous infusion (mean time 17 days). In children with intravenous glucose infusion, blood was also collected once after a minimum $8 \mathrm{~h}$ of continuous infusion (mean time $8.5 \mathrm{~h}$ ).

Blood samples for peptide determination were collected in chilled glass tubes containing 4 mg EDTA and 0.2 TIU (trypsin inhibitor units) of aprotinin (Sigma, USA). Immediately after the sampling, the tubes were transported to the laboratory in an icebox. Blood was centrifuged for $10 \mathrm{~min}$ at $3000 \mathrm{~g}$ and $+4 \mathrm{oC}$. Plasma was stored at $-80 \mathrm{oC}$ until the measurements. Leptin (total) concentration was determined using the EASIA method from Biosource (Belgium), ghrelin (total), CCK-8, PYY (3-36), GLP-1 (7-36 amid) and adiponectin levels were measured using EIA (Phoenix Pharmaceuticals, Inc, USA). Glucose levels in the sera were determined using an enzymatic method with glucose oxidase (Vitros 5.1, Ortho Clinical Diagnostics, USA). 


\subsection{Statistical Analysis}

In all estimations the intra-assay coefficient of variation was below $5 \%$. Differences between groups were tested for statistical significance using one-way analysis of variance followed by the Bonferroni multiple comparison procedure or, when appropriate, by Student's t-test (paired when compared parameters before and after feeding in the same group). Parametric and non-parametric Spearman rank correlations were used to evaluate relations between different variables. $P \leq .05$ was considered significant.

\section{RESULTS AND DISCUSSION}

There were no statistical differences in age between the studied groups; however, there was a significant difference in weight between group II and group III $(P=.009)$, (Table 1$)$.

Table 1. Clinical characteristics of studied groups.Significant differences (Student's t-test) between groups are marked with an asterisk (* $p=.009)$

\begin{tabular}{llll}
\hline Group & I & II & III \\
\hline Number of children & $\mathrm{n}=16$ & $\mathrm{n}=14$ & $\mathrm{n}=15$ \\
& 9 girls and 7 boys & 6 girls and 8 boys & 6 girls and 9 boys \\
Age [months] & $4.0 \pm 1.0$ & $4.0 \pm 2.0$ & $4.5 \pm 1.5$ \\
Weight [kg] & $5.5 \pm 0.8$ & $4.9 \pm 1.8^{*}$ & $6.3 \pm 1.9^{*}$ \\
\hline
\end{tabular}

Energy consumption in group I was calculated from the volume of ingested formula-milk over 24 hours, taking into account the body weight and energy value of the consumed milk reported by the manufacturer. The children from group I consumed $108 \pm 18 \mathrm{kcal} / \mathrm{kg} / 24 \mathrm{~h}$, and caloric intake in this group was significantly higher than in children fed parenterally $(P<.001$ in both cases). Children with TPN (group II) received $60 \pm 8 \mathrm{kcal} / \mathrm{kg} / 24 \mathrm{~h}$, whereas children maintained on an i.v. saline/glucose mixture (group III) received only $37 \pm 6 \mathrm{kcal} / \mathrm{kg} / 24 \mathrm{~h}$. The differences in caloric intake between these two groups were also statistically significant $(P<.001)$.

\subsection{Glucose}

The mean value of fasting glucose level in group I $(4.7 \pm 0.3 \mathrm{mmol} / \mathrm{l})$ was significantly less than the mean value obtained one hour after the meal $(5.1 \pm 0.8 \mathrm{mmol} / \mathrm{l})$ (Student's paired test; Fig. 1). In children on total parenteral nutrition with intravenous infusion of glucose and crystalloids, the mean glucose levels were similar $(4.7 \pm 1.2 \mathrm{mmol} / /$ and $5.7 \pm 1.4 \mathrm{mmol} / \mathrm{l}$, respectively). There were no statistically significant differences between postprandial glucose levels in group I and group II. However, the serum glucose concentration in group II was significantly higher than in group III $(P=.03)$ (Fig. 1).

\subsection{Ghrelin}

The concentration of ghrelin in group I increased after the meal (before $0.5 \pm 0.27 \mathrm{ng} / \mathrm{ml}$; after the meal $0.76 \pm 0.26 \mathrm{ng} / \mathrm{ml}, P=.017$ ). In groups II and III, ghrelin levels were similar $(0.73 \pm 0.3 \mathrm{ng} / \mathrm{ml}$ and $0.69 \pm 0.3 \mathrm{ng} / \mathrm{ml}$, respectively) and resembled those observed in children from group I after the meal (Fig. 1). 


\subsection{CCK}

The mean fasting CCK concentration in group I $(0.17 \pm 0.08 \mathrm{ng} / \mathrm{ml})$ was significantly lower than in the same children after the meal $(0.24 \pm 0.07 \mathrm{ng} / \mathrm{ml})$. The mean concentration of this peptide one hour after the meal was significantly higher than the mean concentrations of CCK in group II $(0.14 \pm 0.08 \mathrm{ng} / \mathrm{ml}, P=.002)$ ) or group III $(0.16 \pm 0.11 \mathrm{ng} / \mathrm{ml}, P=.01)$, (Fig. 1).

\subsection{GLP-1}

The mean fasting concentration of GLP-1 in group I $(0.48 \pm 0.12 \mathrm{ng} / \mathrm{ml})$ did not differ statistically from the mean postprandial concentrations $(0.56 \pm 0.18 \mathrm{ng} / \mathrm{ml})$ as well as mean GLP-1 concentrations in group II $(0.51 \pm 0.25 \mathrm{ng} / \mathrm{ml})$ and III $(0.52 \pm 0.23 \mathrm{ng} / \mathrm{ml})$ were similar (Fig. 1).

\subsection{PYY}

The mean PYY concentration in group I was similar before $(1.45 \pm 0.68 \mathrm{ng} / \mathrm{ml})$ and after the meal $(1.78 \pm 0.65 \mathrm{ng} / \mathrm{ml})$. These values were significantly higher $(P<.001)$ than the mean PYY concentrations in group II $(1.13 \pm 0.37 \mathrm{ng} / \mathrm{ml})$ and III $(0.72 \pm 0.15 \mathrm{ng} / \mathrm{ml})$. There was also a significant difference between the concentrations in the two latter groups $(P<.001)$, (Fig. 1).

\subsection{Leptin}

The mean plasma concentration of leptin in group I prior to the meal $(1.46 \mathrm{mg} / \mathrm{ml} \pm 0.52)$ was similar to that observed after the meal $(1.48 \mathrm{mg} / \mathrm{ml} \pm 0.46)$. In group III the leptin levels $(1.48 \mathrm{mg} / \mathrm{ml} \pm 0.45)$ resembled these observed in the children fed milk formula. Only in group II was the mean plasma leptin concentration was significantly lower than in the preceding groups $(1.08 \mathrm{mg} / \mathrm{ml} \pm 0.43 ; P<.005$ in both cases), (Fig. 1$)$.

\subsection{Adiponectin}

The mean adiponectin levels in group I were almost the same before $(10.7 \mu \mathrm{g} / \mathrm{ml} \pm 2.2)$ and one hour after the meal $(10.7 \mu \mathrm{g} / \mathrm{ml} \pm 2.4)$. These values were significantly higher than the mean plasma adiponectin concentrations in group II $(5.8 \mu \mathrm{g} / \mathrm{ml} \pm 2.4 ; P<.001)$ and group III $(3.3 \mu \mathrm{g} / \mathrm{ml} \pm 2.3 ; P<.001)$, (Fig. 1).

\subsection{Correlations}

In group I significant correlations were found between CCK and ghrelin levels $(r=0.57$; $P=.021$ ). Concentrations of GLP-1 were also correlated to PYY concentrations ( $r$ 0.52; $P=$.039). In group II no correlations between studied parameters were noted. In group III there were also significant correlations between CCK and ghrelin concentrations $(r=0.59$; $P=.021)$. In this group alone a significant correlation between gastrointestinal peptide and peptide from adipose tissue was noted (PYY: leptin $(r=-0.75 ; P<.001)$ ). Also, a significant correlation was found between adiponectin and leptin only in group III ( $r=0.62, P=.014$ ). Analyzing the data from all the studied children, a significant positive correlation was found between caloric intake and the plasma concentrations of some of the peptides: adiponectin $(\mathrm{r}=0.76, P<.001)$, PYY $(\mathrm{r}=0.76, P<.001)$ and CCK $(\mathrm{r}=0.50 ; P<.001)$. Also, a significant relation was noted between PYY and CCK $(r=0.54, P<.001)$ as well as between PYY and adiponectin $(r=0.64, P<.001)$. 


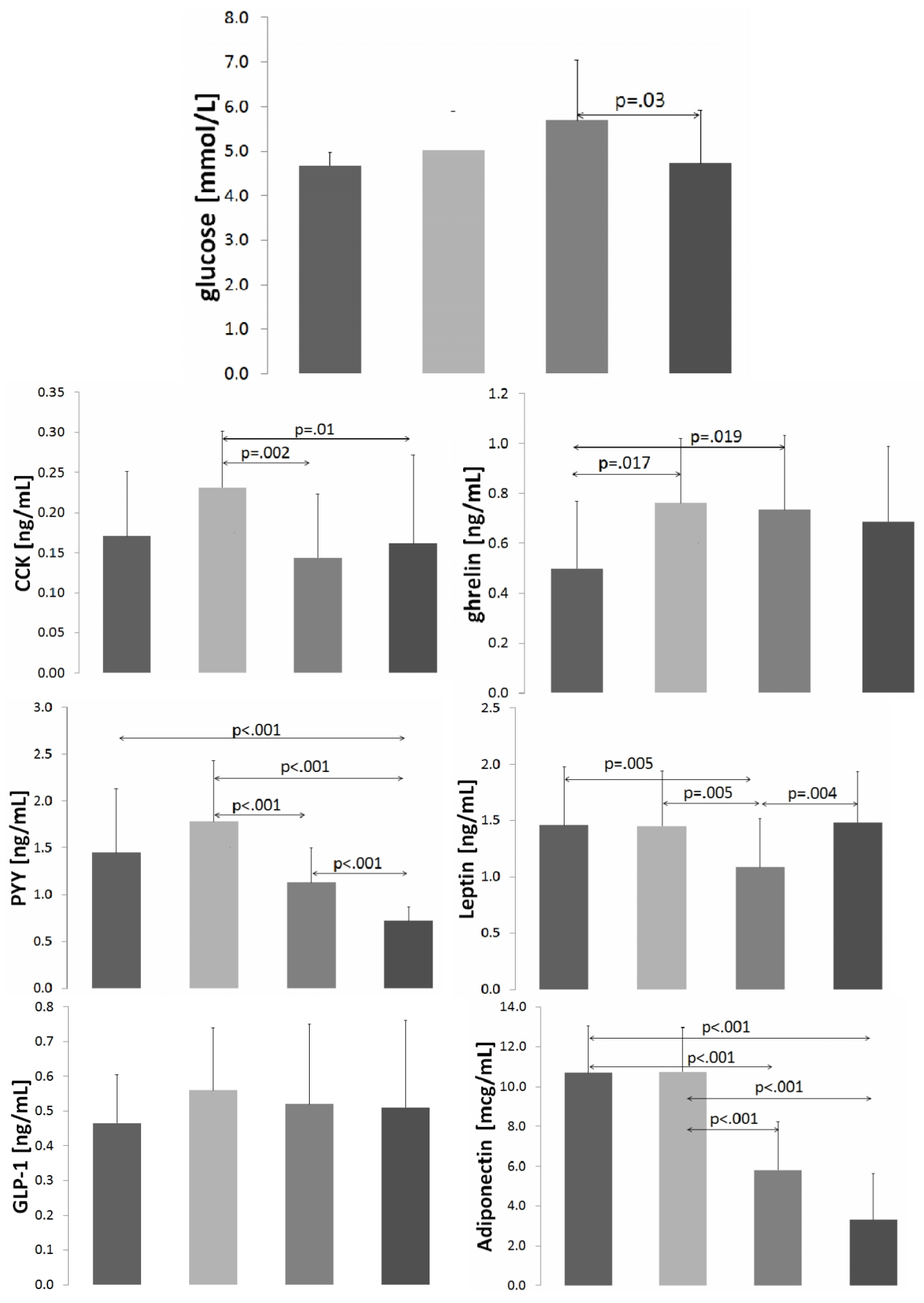

Fig. 1 . Mean concentrations of glucose and analyzed peptides in studied groups. Group I - healthy infants, group II - infants fed with total parenteral nutrition over 24 hrs, group III - healthy infants hydrated intravenously at least 8 hrs. The statistically significant differences (using one-way analysis of variance followed by the Bonferroni multiple comparison) were marked with arrows 
There have been very few papers describing the effects of parenteral nutrition on regulatory peptides. The results have been contradictory due to several confounding factors such as the age of the patients and their caloric needs, primary illnesses, the duration of parenteral therapy per se, and the duration of the infusion per day. Most importantly, the ratio between parenteral and enteral energy delivery should be taken into account. In the course of this study only infants whose calories were provided entirely parenterally (total parenteral nutrition) were tested. The infusions were provided on an around the clock schedule, to cover caloric needs and decrease potential metabolic (acidosis) and clinical side effects (venous inflammation).

In this study there were no differences in mean CCK concentrations in TPN children and children hydrated intravenously. Moreover, these concentrations resembled those observed in fasted but originally orally fed children, but were significantly lower than postprandial in formula-fed children. Those observations are similar to data of Mashako et al. [25]. However, Shirohara et al. [26] observed that blood levels of CCK in parenterally fed patients depend on the concentrations of individual amino acids used in the given mixture. Two of the most typical long-term side effects of TPN are gallstones and gallbladder sludge [27,28], probably due to the absence of the characteristic postprandial increase in CCK secretion in TPN children. The solution is to alternate different mixtures to alternately stimulate and inhibit CCK secretion with subsequent release and constriction of the gallbladder. The data on i.v. delivery of CCK in TPN patients are conflicting [29-31]. It is possible that exogenous CCK in patients receiving mixtures stimulating CCK secretion itself is ineffective.

It seems that in infants the means of delivery and the amount of delivered energy does not have any effect on GLP-1 levels in blood plasma. Moreover, the lack of correlation between glucose and GLP-1 concentrations suggests that the incretin action of this peptide in infants is weak.

In this study, plasma ghrelin concentrations during total parenteral nutrition mimicked the postprandial levels observed in enterally fed children. The observation that parenteral nutrition in a group with short bowel syndrome evoked changes in ghrelin such as oral bolus in patients on enteral nutrition agrees with data in the sole paper on the subject published by Murray et al. who analyzed ghrelin in parenterally fed humans [32]. The most harmful sideeffect in children fed parenterally for a long time could be the constant stimulation of ghrelin secretion with no intrameal modulation. As recorded by Bonifacio et al., in patients on longterm parenteral nutrition, BMI subsequently increases year by year [33]. This phenomenon might be related to the continuous stimulation of orexigenic peptide secretion and their anabolic properties.

The role of leptin in the long-term regulation of energy balance, mainly through controlling the volume of body fat, is well known. Several studies have shown changes in leptin levels in at least $24 \mathrm{~h}$ periods of under- or overeating [34-36], whereas older studies did not demonstrate a short-term relationship between plasma leptin and food intake $[37,38]$. The present study correlates with the findings above in that short-term calorie deprivation - less than 12 hours - in fasted children hydrated intravenously did not influence leptin levels. However, long-term TPN [group II] produced significantly diminished plasma leptin levels compared to the orally fed ad libitum children from group III. In the study by Molina et al., leptin concentrations in patients on long-term TPN were similar to those observed in healthy, orally fed individuals. The correlation between leptin and BMI was also evident [39]. It seems that the reduced leptin levels compared to other studied groups is connected with the lower 
weight as well as lower BMI in the children in group II; however; neither leptin:weight nor leptin: BMI were significantly correlated.

The present study also provides some new data about leptin-adiponectin relations. Leptin correlates positively with adiponectin in foetuses as well as in cord blood, but in older children (5-10 yrs) a negative correlation between these peptides has been observed [4042]. In this study a weak but significant, correlation was found between leptin and adiponectin concentrations in children only hydrated intravenously (group III). It seems that the relationship between leptin and adiponectin changes during the first years of life. The positive correlation typical of prenatal life declines in infants, probably due to atrophy of brown fat tissue; however, at that age a negative correlation, typical of older children, has not yet been established due to insufficient white fat.

Short-term fasting diminishes plasma PYY levels [43]. The present study confirms this observation - the lowest mean PYY plasma concentration was found in group III. In the present study a significant positive correlation was observed between plasma PYY levels and energy intake in infants. These data partially confirm the observations of Chen et al. [44] that PYY plasma concentrations correlate with a negative energy balance. The other explanation for reduced PYY concentrations in children fed parenterally is the typical action of PYY. This peptide inhibits digestion when nutrients are absorbed from the lumen [45]. Therefore, a finding of low plasma PYY in the absence of nutrients in the gut, when there are no processes to inhibit, is self-evident. The reduced PYY concentrations in children with parenteral nutrition are consistent with data presented by Murray et al. [32].

Data about the influence of food intake on adiponectin secretion and plasma concentration are conflicting. Our study showed no changes in adiponectin levels in healthy infants after a meal, supporting the observations of Paeke et al. that adiponectin levels do not change in response to an oral meal [46]. The absence of meal-stimulated modulation of adiponectin plasma levels in infants could be related to the high frequency of meals given to infants and the constant filling of the gut. In parenterally fed children plasma adiponectin concentrations were lower than in orally fed children. What is more, a significant positive correlation was found between energy/calorie intake and adiponectin plasma concentration in the studied children. These data, suggest that adiponectin could be a good marker for short and ultrashort-term energy balance estimation in a "dose dependent" manner.

Limitation of the study: The small size of the study groups makes more profound analysis difficult. Lack of the fasting values in group II resulted from the serious disturbances in those children finally led to TPN. Therefore comparisons of fasting values were excluded from study protocol. The important bias in this study is related to the diseases of children in group II. Orally feed children and healthy children hydrated intravenously were compared with patients suffering from either congenital bowel atresia or acquired obstruction of the gastrointestinal tract (before or after surgery) tract and it cannot be excluded that the difference observed here can be attributed, at least partially, to the affection of the gastrointestinal tract in children feed by TPN. However, the potential influence was minimized - the tests were performed after several days after initiating of TPN, in stable clinical conditions. 


\section{CONCLUSION}

Feeding does not influence plasma concentrations of leptin or adiponectin in infants.

The absence of fasting/postprandial modulation of secretion of gut peptides might be responsible for the disturbed development of parenterally fed children.

Adiponectin and PYY are putative markers of short-term energy balance.

\section{CONSENT}

All authors declare that 'written informed consent was obtained from the parents of children enrolled to the study.

\section{ETHICAL APPROVAL}

All authors hereby declare that all experiments have been examined and approved by the appropriate ethics committee and have therefore been performed in accordance with the ethical standards laid down in the 1964 Declaration of Helsinki.

\section{COMPETING INTERESTS}

Authors have declared that no competing interests exist.

\section{REFERENCES}

1. Kojima M, Hosoda H, Date $Y$, Nakazato M, Matsuo H, Kangawa K. Ghrelin is a growth-hormone-releasing acylated peptide from stomach. Nature 1999;402:656-60.

2. Pombo M, Pombo CM, Garcia A, Caminos E, Gualillo O, Alvarez CV, Casanueva FF, Dieguez C. Hormonal control of growth hormone secretion. Horm Res. 2001;55(Suppl1):11-16.

3. Ellis AC, Casazza K, Chandler-Laney P, Gower BA. Higher postprandial serum ghrelin among African-American girls before puberty. J Pediatr Endocrinol Metab. 2012;25:691-696.

4. Tomasik PJ, Sztefko K. The effect of enteral and parenteral feeding on secretion of orexigenic peptides in infants. BMC Gastroenterol. 2009;9:92.

5. Strohacker K, McCaffery JM, Maclean PS, Wing RR. Adaptations of leptin, ghrelin or insulin during weight loss as predictors of weight regain: A review of current literature. Int J Obes (Lond); 2013. [Epub ahead of print].

6. Adrian TE, Ferri GL, Bacarese-Hamilton AJ, Fuessl HS, Polak JM, Bloom SR. Human distribution and release of a putative new gut hormone peptide YY. Gastroenterology 1985;89:1070-1077.

7. El-Salhy M, Mazzawi T, Gundersen Dm, Hatlebakk JG, Hausken T. The role of peptide $Y Y$ in gastrointestinal diseases and disorders (review). Int $\mathrm{J}$ Mol Med. 2013;31:275-282. DOI: 10.3892/ijmm.2012.1222.

8. De Silva A, Salem V, Long CJ, Makwana A, Newbould RD, Rabiner EA, Ghatei MA, Bloom SR, Matthews PM, Beaver JD, Dhillo WS. The gut hormones PYY 3-36 and GLP-1 7-36 amide reduce food intake and modulate brain activity in appetite centers in humans. Cell Metab. 2011;14:700-706. DOI: 10.1016/j.cmet.2011.09.010. 
9. Orskov C, Holst JJ, Poulsen SS, Kirkegaard P. Pancreatic and intestinal processing of proglucagon in man. Diabetologia 1987;30:874-881.

10. Fehmann HC, Goke R, Goke B. Cell and molecular biology of the incretin hormones glucagon-like peptide-I and glucose-dependent insulin releasing polypeptide. Endocrine Rev. 1995;15:390-407.

11. Marathe CS, Rayner CK, Jones KL, Horowitz M. Effects of GLP-1 and incretin-based therapies on gastrointestinal motor function. Exp Diabetes Res. 2011;279530.

12. Zoicas F, Droste M, Mayr B, Buchfelder M, Schöfl C. GLP-1 analogues as a new treatment option for hypothalamic obesity in adults: Report of nine cases. Eur $\mathrm{J}$ Endocrinol. 2013;168:699-706. DOI: 10.1530/EJE-12-0997.

13. Wikarek T, Chudek J, Owczarek A, Olszanecka-Glinianowicz M. Effect of dietary macronutrients on postprandial incretin hormone release and satiety in obese and normal-weight women. Br J Nutr. 2013;1-11.

14. Liddle RA, Goldfine ID, Rosen MS, Taplitz RA, Williams JA. Cholecystokinin bioactivity in human plasma: Molecular forms responses to feeding and relationship to gallbladder contraction. J Clin Invest. 1985;75:1144-1152.

15. Chandra R, Liddle RA. Recent advances in pancreatic endocrine and exocrine secretion. Curr Opin Gastroenterol. 2011;27:439-43.

16. Tomasik PJ, Sztefko K, Starzyk J, Rogatko I, Szafran Z. Entero-insular axis in children with anorexia nervosa. Psychoneuroendocrinology. 2005;30:364-72.

17. Dockray GJ. Cholecystokinin and gut-brain signalling. Regul Pept. 2009;155:6-10.

18. Ahima RS, Flier JS. Leptin. Annu Rev Physiol. 2000;62:413-437.

19. Hoppin AG, Kaplan LM. The leptin era: New insight into the mechanisms of body weight homeostasis. J Pediatr Gastroenterol Nutr. 1999;29:250-264.

20. Berg AH, Combs TP, Du X, Brownlee M, Scherer PE. The adipocyte-secreted protein Acrp30 enhances hepatic insulin action. Nat Med. 2001;7:47-953.

21. Tsao T S, Lodish H F, Fruebis J. ACRP30 a new hormone controlling fat and glucose metabolism. Eur J Pharmacol. 2002;440:213-221.

22. Bacha F, Saad R, Gungor N, Arslanian SA. Adiponectin in youth. Relationship to visceral adiposity insulin sensitivity and ß-cell function. Diabetes Care. 2004;27:547552.

23. Karczewska-Kupczewska M, Straczkowski M, Adamska A, Nikołajuk A, Otziomek E, Górska M, Kowalska I. Insulin sensitivity metabolic flexibility and serum adiponectin concentration in women with anorexia nervosa. Metabolism. 2010;59:473-477. DOI: 10.1016/j.metabol.2009.07.036.

24. Available: http://pediatria.mp.pl/prawidlowyrozwoj/rozwojfizyczny/show.html?id=52272.

25. Mashako MN, Bernard C, Cezard JP, Chayvialle JA, Navarro J. Effect of total parenteral nutrition constant rate enteral nutrition and discontinuous oral feeding on plasma cholecystokinin immunoreactivity in children. J Pediatr Gastroenterol Nutr. 1987;6:948-952.

26. Shirohara H, Tabaru A, Otsuki M. Effects of intravenous infusion of amino acids on cholecystokinin release and gallbladder contraction in humans. J Gastroenterol. 1996;31:572-577.

27. Dray X, Joly F, Reijasse D, Attar A, Alves A, Panis $Y$, Valleur P, Messing B. Incidence risk factors and complications of cholelithiasis in patients with home parenteral nutrition. J Am Coll Surg. 2007;204:13-21.

28. Bogue CO, Murphy AJ, Gerstle JT, Moineddin R, Daneman A. Risk factors, complications, and outcomes of gallstones in children: A single-center review. J Pediatr Gastroenterol Nutr. 2010;50:303-308. DOI: 10.1097/MPG.0b013e3181b99c72. 
29. Sitzmann JV, Pitt HA, Steinborn PA, Pasha ZR, Sanders RC. Cholecystokinin prevents parenteral nutrition induced biliary sludge in humans. Surg Gynecol Obstet 1990;170:25-31.

30. Teitelbaum DH, Tracy TF Jr, Aouthmany MM, Llanos A, Brown MB, Yu S, Brown MR, Shulman RJ, Hirschl RB, Derusso PA, Cox J, Dahlgren J, Groner JI, Strouse PJ. Use of cholecystokinin-octapeptide for the prevention of parenteral nutrition-associated cholestasis. Pediatrics. 2005;115:1332-1340.

31. Tsai S, Strouse PJ, Drongowski RA, Islam S, Teitelbaum DH. Failure of cholecystokinin-octapeptide to prevent TPN-associated gallstone disease. J Pediatr Surg. 2005;40:263-267.

32. Murray CD, le Roux CW, Gouveia C, Bassett P, Ghatei MA, Bloom SR, Emmanuel AV, Gabe SM. The effect of different macronutrient infusions on appetite ghrelin and peptide $Y Y$ in parenterally fed patients. Clin Nutr. 2006;25:626-633.

33. Bonifacio R, Alfonsi L, Santarpia L, Orban A, Celona A, Negro G, Pasanisi F, Contaldo $F$. Clinical outcome of long-term home parenteral nutrition in nononcological patients: A report from two specialisedcentres. Intern Emerg Med. 2007;2:188-195.

34. Kolaczynski J, Ohannesian JP, Considine RV, Marco CC, Caro JF. Response of leptin to short-term and prolonged overfeeding in humans. J Clin Endocrinol Metab. 1996;91:4162-4165.

35. Izadpanah A, Barnard RJ, Almeda AJ, Baldwin GC, Bridges SA, Shellman ER, Burant $\mathrm{CF}$, Roberts CK. A short-term diet and exercise intervention ameliorates inflammation and markers of metabolic health in overweight/obese children. Am J Physiol Endocrinol Metab. 2012;303. E542-50. DOI: 10.1152/ajpendo.00190.2012.

36. Morel O, Luca F, Grunebaum L, Jesel L, Meyer N, Desprez D, Robert S, DignatGeorge F, Toti F, Simon C, Goichot B. Short-term very low-calorie diet in obese females improves the haemostatic balance through the reduction of leptin levels, PAI1 concentrations and a diminished release of platelet and leukocyte-derived microparticles. Int J Obes (Lond). 2011;35:1479-1486. DOI: 10.1038/ijo.2011.19.

37. Joannic JL, Oppert JM, Lahlou N, Basdevant A, Auboiron S, Raison J, Bornet F, GuyGrand B. Plasma leptin and hunger ratings in healthy humans. Appetite 1998;30:129138.

38. Karhunen L, Haffner S, Lappalainen R, Turpeinen A, Miettinen H, Uusitupa M. Serum leptin and short-term regulation of eating in obese women. Clin Sci (Lond) 1997;92:573-578.

39. Molina A, Pita A, Farriol M, Virgili N, Soler J, Gómez JM. Serum leptin concentrations in patients with short-bowel syndrome. Clin Nutr. 2000;19:333-338.

40. Matsuda J, Yokota I, lida M, Murakami T, Naito E, Ito M, Shima K, Kuroda Y. Serum leptin concentrations in cord blood: Relationship to birth weight and gender. J Clin Endocrinol Metab 1997;82:1642-1644.

41. Marinoni E, Corona G, Ciardo F, Letizia C, Moscarini M, Di lorio R. Changes in the interrelationship between leptin, resistin and adiponectin in early neonatal life. Front Biosci (Elite Ed). 2010;2:52-58.

42. Stefan N, Bunt JC, Salbe AD, Funahashi T, Matsuzawa Y, Tataranni PA. Plasma adiponectin concentrations in children: Relationships with obesity and insulinemia. $J$ Clin Endocrinol Metab. 2002;87:4652-4656.

43. Beer SF, Bircham PM, Bloom SR Clark PM, Hales CN, Hughes CM, Jones CT, Marsh DR, Raggatt PR, Findlay AL. The effect of a 72-h fast on plasma levels of pituitary adrenal thyroid pancreatic and gastrointestinal hormones in healthy men and women. J Endocrinol. 1989;120:337-350. 
44. Chen X, Du X, Zhu J Xie L, Zhang Y, He Z. Correlations of circulating peptide $Y Y$ and ghrelin with body weight rate of weight gain and time required to achieve the recommended daily intake in preterm infants. Braz J Med Biol Res. 2012;45:656-664.

45. Konturek SJ, Pepera J, Zabielski K, Konturek PC, Pawlik T, Szlachcic A, Hahn EG. Brain-gut axis in pancreatic secretion and appetite control. J Physiol Pharmacol. 2003;54:293-317.

46. Peake PW, Kriketos AD, Denyer GS Campbell LV, Charlesworth JA. The postprandial response of adiponectin to a high-fat meal in normal and insulin-resistant subjects. Int J Obes Relat Metab Disord. 2003;27:657-662.

(c) 2014 Tomasik et al.; This is an Open Access article distributed under the terms of the Creative Commons Attribution License (http://creativecommons.org/licenses/by/3.0), which permits unrestricted use, distribution, and reproduction in any medium, provided the original work is properly cited.

Peer-review history:

The peer review history for this paper can be accessed here:

http://www.sciencedomain.org/review-history.php?iid=582\&id=32\&aid=5207 